\title{
Effects of Abeliophyllum distichum Nakai Flower Extracts on Antioxidative Activities and Inhibition of DNA Damage
}

\author{
Joungjwa Ahn and Jae Ho Park ${ }^{1 *}$ \\ Department of Food Science and Industry, Jungwon University, Goesan 367-805, Korea \\ ${ }^{1}$ Department of Medicinal Plant Science, Jungwon University, Goesan 367-805, Korea
}

\begin{abstract}
The present study attempts to evaluate antioxidant activities of extracts from Abeliophyllum distichum. Nakai flower. The samples were collected in Jangyyeon-myeon, Goesan-gun, Korea and extracted with either hot-water or ethyl acetate (EtOAC). In DPPH, hydroxyl radical scavenging activity and $\mathrm{Fe}^{2+}$ chelating activity of EtOAC extracts were 93.41\%, 98.43\%, and 7.38\%, while those of hot-water extracts were $86.93 \%, 41.33 \%$ and $47.68 \%$ at $200 \mu \mathrm{g} / \mathrm{ml}$, respectively. In $\varphi$ X-174 RF I plasmid DNA cleavage assay, the protective effects of EtOAC and hot-water extracts against oxidative DNA damage were $82 \%$ and $17 \%$ at $200 \mu \mathrm{g} / \mathrm{ml}$, respectively. Both extracts showed the protective effect of DNA migration by oxidative stress in intracellular DNA migration assay. Both extracts had no cytotoxity in NIH3T3 cells. Several polyphenolic compounds were identified such as 2-methoxy-benzoic acid, vanillic acid, phytol and pulegone by GC/MS. These results indicated that extracts of Abeliophyllum distichum Nakai flower showed antioxidant activities and protective activities against oxidative DNA damage and showed the possibility to be used as an effective natural antioxidants.
\end{abstract}

Key words - Abeliophyllum distichum Nakai flower, Antioxidant, DNA damage, Cytotoxity, Phenolic compounds

\section{Introduction}

The Abeliophyllum distichum Nakai is momotypic taxon of Oleaceae and endemic to Korea. This deciduous shrub is related to the forsythia, but differs in that it has white (rather than yellow) flowers that open in early spring before true forsythia. Now in Korea, the 5 natural habitats of Abeliophyllum distichum Nakai has been designated and protected as a natural monument. Consequently, the study about Abeliophyllum distichum Nakai has been emphasized on the botanical characterization and mass propagation.

In living organisms, various reactive oxygen species (ROS) e.g., superoxide anions $\left(\mathrm{O}_{2}{ }^{-}\right)$, hydroxyl radicals $(\mathrm{OH})$, and non-radical compounds, can be formed by different mechanisms. These ROS may induce oxidative damage to various biomolecules in cells such as carbohydrates, proteins, lipids and DNA which in turn leads to cardiovascular and neurodegenerative diseases, inflammation and others (Ames, 1983; Stadtman, 1992; Sun, 1990). At least two major human problems aging, and cancer, involve ROS mediated DNA damage (Cerutti, 1994; Wiseman and Halliwell, 1996).

Synthetic antioxidants like butylated hydroxytoluene (BHT) and butylated hydroxyanisole (BHA) commonly used in processed foods have side effects and are carcinogenic(Ali et al., 2008). The medicinal properties of plants have been investigated in the recent scientific developments throughout the world, due to their potent antioxidant activities, no side effects and economic viability(Auudy et al., 2003). Plant phytochemicals viz phenolic compounds, flavonoids and tannins reported to possess significant antioxidant activity against a wide variety of free radicals (Kirmizibekmez et al., 2009; Choudhary and Swarnkar 2011; Koleckar et al., 2008). These active compounds can be isolated and developed as natural drugs for prevention and treatment of free radical related diseases.

Therefore, in this study, we demonstrate the protective effect on oxidative DNA damage of extracts from Abeliophyllum distichum Nakai via its antioxidant activity for the establishment of new value for the herbal medicine.

${ }^{\star}$ Corresponding author. E-mail : parkjh@jwu.ac.kr 


\section{Materials and Methods}

\section{Materials}

Abeliophyllum distichum Nakai flower were collected at Jangyyeon-myeon Goesan-gun, Korea.

\section{EtOAC extraction}

Five hundred grams of fresh flower was extracted with $1,000 \mathrm{ml}$ of $80 \%$ methanol with shaking for $24 \mathrm{hr}$. Then, the methanolsoluble fraction was filtered and concentrated to approximately $20 \mathrm{ml}$ volume using a vacuum evaporator and a fraction was placed in a separating funnel. The ethyl acetate fraction was separated from the mixture, evaporated by a vacuum evaporator and prepared aseptically and kept in a refrigerator until use. The recovery of EtOAC extracts was about $0.1 \%(w / w)$.

\section{Hot-water extraction}

Five hundred grams of flower was boiled in $1,000 \mathrm{ml}$ of hot-water for $2 \mathrm{hrs,} \mathrm{filtered} \mathrm{and} \mathrm{lyophilized} \mathrm{with} \mathrm{freeze-dryer.}$ The recovery of hot-water extracts was about $0.3 \%(w / w)$.

\section{DPPH radical scavenging activity}

The antioxidant activity of the extracts was evaluated first by monitoring its ability in quenching the stable free radical DPPH. Reaction mixture containing $40 \mu$ lof test samples (4 mg $/ \mathrm{ml}$ dissolved in DMSO) and $760 \mu \mathrm{l}$ of $300 \mu \mathrm{M}$ DPPH ethanol solution in micro tube were incubated at $37^{\circ} \mathrm{C}$ for $30 \mathrm{~min}$ and absorbance was measured at $515 \mathrm{~nm}$ according to the increasing concentrations. The DPPH quenching ability was calculated from the log-dose inhibition curve. All determination was carried out in triplicate.

\section{Hydroxyl radical scavenging activity}

Hydroxyl radical-scavenger ability was measured according to a literature procedure (Smirnoff and Cumbes, 1989) with a few modifications. Hydroxyl radical was generated from $\mathrm{FeSO}_{4}$ and hydrogen peroxide, and detected by their ability to hydroxylate salicylate. The reaction mixture $(800 \mu \mathrm{l})$ contained $250 \mu \mathrm{l}$ $\mathrm{FeSO}_{4}(1.5 \mathrm{mM}), 175 \mu \mathrm{l}$ hydrogen peroxide $(6 \mathrm{mM}), 300 \mu \mathrm{l}$ sodium salicylate $(20 \mathrm{mM})$ and varying concentrations of the fractions. After a reaction for $30 \mathrm{~min}$ at $37^{\circ} \mathrm{C}$, the absorbance of the hydroxylated salicylate complex was measured at $562 \mathrm{~nm}$.
Hydroxyl radical-scavenger ability was calculated from the log-dose inhibition curve. All determination was carried out in triplicate.

\section{$\mathrm{Fe}^{2+}$-chelating activity assay}

This assay was measured according to a literature procedure (Rosenkranz et al., 1992) with a few modifications. The reaction mixture $(800 \mu \mathrm{l})$ contained $15 \mu \mathrm{l} \mathrm{FeCl} 2(2 \mathrm{mM}), 150 \mu \mathrm{l}$ varying concentrations of the extracts and $605 \mu \mathrm{l}$ distilled water. The mixture was shaken vigorously and left at room temperature for $30 \mathrm{~min}$. After $30 \mathrm{~min}, 30 \mu \mathrm{l}$ ferrozine ( $5 \mathrm{mM}$ in methanol) was added and mixed. The absorbance of the $\mathrm{Fe}^{2+}$-ferrozine complex was measured at $562 \mathrm{~nm}$. $\mathrm{Fe}^{2+}$-chelating activity assay was calculated from the log-dose inhibition curve. All determination was carried out in triplicate.

\section{$\varphi X-174$ RF I plasmid DNA cleavage assay}

Conversion of the supercoiled form of plasmid DNA to the open-circular and further linear forms has been used as an index of DNA damage (Jung and Surh, 2001). Reaction mixtures $(25 \mu \mathrm{l})$ contained $5 \mu \mathrm{l}$ of $\varphi \mathrm{X}-174 \mathrm{RF}$ I plasmid DNA, $10 \mu \mathrm{l}$ of varying concentrations of the extracts, $5 \mu \mathrm{l}$ of $1 \mathrm{mM} \mathrm{FeSO}_{4}$ or/and $5 \mu \mathrm{l}$ of $1 \mathrm{mM}$ hydrogen peroxide and were incubated at $37^{\circ} \mathrm{C}$ for 30 min. After $30 \mathrm{~min}, 5 \mu \mathrm{l}$ of a solution containing $50 \%$ glycerol (v/v), $40 \mathrm{mM}$ EDTA and $0.05 \%$ bromophenol blue was added to stop the reaction and the reaction mixtures was electrophoresed on $1 \%$ agarose gel, and the DNA in the gel was visualized and photographed under ultraviolet light after ethidium bromide staining.

\section{Intracellular DNA migration assay}

This assay was carried according to literature procedure (Cho et al., 2008) with some modifications. NIH 3T3 cells $(2 \times$ $10^{6}$ ) were cultured in 6-well plates for 24 hours at $37^{\circ} \mathrm{C}$. After the cells were treated with the varying concentrations of the extracts for $30 \mathrm{~min}$ and then added with $1 \mathrm{mM} \mathrm{FeSO}_{4}$ and $1 \mathrm{mM}$ $\mathrm{H}_{2} \mathrm{O}_{2}$ for 1 hour. After 1 hour, each cell was harvested and then the supernatant was discarded. Each cell was re-suspended with $20 \mu \mathrm{l}$ of lysis buffer (50 mM Tris-HCl, pH 8.0, 10 mM EDTA, $0.5 \%$ SDS and $0.5 \mathrm{mg} / \mathrm{ml}$ proteinase $\mathrm{K}$ ) and then incubated at $55^{\circ} \mathrm{C}$ for $60 \mathrm{~min}$. After lysis of the cells, each cell was centrifuged, $5 \mu \mathrm{l}$ of RNase A was added to the supernatant, and 
each cell was incubated at $55^{\circ} \mathrm{C}$ for another 60 min. After 60 min, each cell was spun briefly to remove any further cell debris and each supernatant was collected. Each lysate was heated at $70{ }^{\circ} \mathrm{C}$ for a few minutes and mixed with $10 \mu \mathrm{l}$ of loading buffer (50\% glycerol (v/v), $40 \mathrm{mM}$ EDTA and $0.05 \%$ bromophenol blue). The reaction mixtures were electrophoresed on $2 \%$ agarose gel, and the DNA in the gel was visualized and photographed under ultraviolet light after ethidium bromide staining.

\section{MTT assay}

NIH 3 T3 cells $\left(5 \times 10^{4}\right)$ were cultured in 96-well plates for 24 hours at $37^{\circ} \mathrm{C}$. After 24 hours, the extracts were treated into each cell according to concentration, and then the cells were incubated at $37^{\circ} \mathrm{C}$ for $30 \mathrm{~min}$. after $30 \mathrm{~min}$, hydroxyl radical was applied to each cell and then the cells were incubated at 3 $7{ }^{\circ} \mathrm{C}$ for 24 hours. After 24 hours, $50 \mu \mathrm{l}$ of MTT solution (1 mg $/ \mathrm{ml}$ ) was treated to each cell for 4 hours. After 4 hours, the supernatant was removed, and then $100 \mu \mathrm{l}$ of DMSO was treated to each cell. The observance was measures with a microplate reader at $570 \mathrm{~nm}$.

\section{GC/MS analysis}

GC/MS analysis for the compositions of ethyl acetate fraction was performed using same GC/MSD, equipped with Ultra 2 column (Crosslinked 5\% PH ME siloxane, HP-19091B). The carrier gas used was helium, at a constant flow rate of 1.0 $\mathrm{ml} / \mathrm{min}$. One microliter of the extract was injected into the column using 10:1 of the split ratio injection mode. The oven temperature was initially held at $100^{\circ} \mathrm{C}$ for $5 \mathrm{~min}$, then raised to $295^{\circ} \mathrm{C}, 4{ }^{\circ} \mathrm{C} / \mathrm{min}$, and finally held at $240^{\circ} \mathrm{C}$ for $5 \mathrm{~min}$. The temperatures of injector and detector were $200^{\circ} \mathrm{C}$ and $240{ }^{\circ} \mathrm{C}$, respectively. Components of the extracts were identified with the aid of the database (Wiley275 mass spectral database, Hewlett-Packard, 1995) or by manual interpretation.

\section{Results}

\section{Antioxidant activity}

Antioxidant activities of Abeliophyllum distichum Nakai flower extracts were measured by DPPH radical scavenging assay, hydroxyl radical scavenging assay and $\mathrm{Fe}^{2+}$ chelating assay. DPPH radical scavenging activities of 2 fractions, aqueous and ethyl acetate (EtOAC) fractions are shown Fig. 1. The DPPH radical scavenging activity of all samples increased with increasing extract concentrations. Ethyl acetate fraction showed higher scavenging activity than aqueous fraction, which were $93.41 \%$ and $86.93 \%$ at $200 \mu \mathrm{g} / \mathrm{ml}$ of extract concentration, respectively (Fig. 1).

In hydroxyl radical scavenging assay, the activity of EtOAC

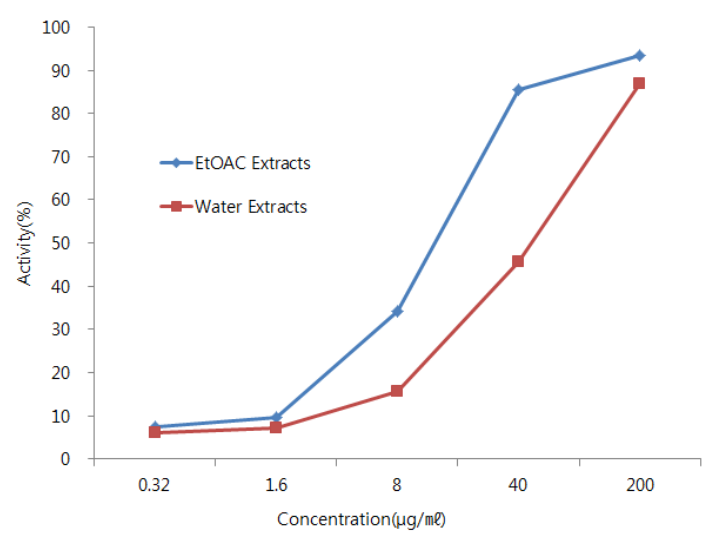

Fig. 1. DPPH radical scavenging activity of the flower extracts from Abeliophyllum distichum Nakai. The reaction mixture was kept at $37^{\circ} \mathrm{C}$ for $30 \mathrm{~min}$ and the absorbance was measured at $515 \mathrm{~nm}$. The absorbance values were converted to DPPH radical scavenging activity (\%) against extract concentration in $\mu \mathrm{g}$ extract per $\mathrm{ml}$ reaction volume.

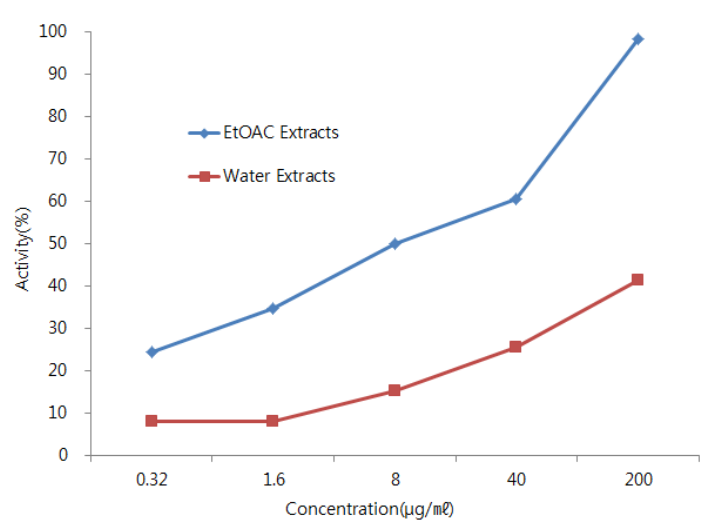

Fig. 2. Hydroxyl radical scavenging activity of the flower extracts from Abeliophyllum distichum Nakai Hydroxyl radical was generated from fenton reaction between $\mathrm{H}_{2} \mathrm{O}_{2}$ and $\mathrm{FeSO}_{4}$. The reaction mixture was kept at $37^{\circ} \mathrm{C}$ for $30 \mathrm{~min}$ and the absorbance was measured at $562 \mathrm{~nm}$. The absorbance values were converted to hydroxyl radical scavenging activity (\%) against extract concentration in $\mu \mathrm{g}$ extract per $\mathrm{ml}$ reaction volume. 
fraction of flower extract increased moderately up to $40 \mu \mathrm{g} / \mathrm{ml}$, however, it increased dramatically up to $200 \mu \mathrm{g} / \mathrm{ml}$ as $98.43 \%$ (Fig. 2). In contrast, aqueous fraction showed lower activities at every concentrations than EtOAC fraction, and the highest hydroxyl radical scavenging was $41.33 \%$ at $200 \mu \mathrm{g} / \mathrm{ml}$.

The $\mathrm{Fe}^{2+}$ chelating ability of samples is shown in Fig. 3. The aqueous fraction showed higher chelating activity than EtOAC fraction (Fig. 3). Aqueous fraction chelated $\mathrm{Fe}^{2+}$ ion by $47.68 \%$ at $200 \mu \mathrm{g} / \mathrm{ml}$, whereas EtOAC fraction showed $7.38 \%$ of $\mathrm{Fe}^{2+}$ chelating ability in same concentration.

\section{Protective effect against oxidative DNA damage}

Protective effect of Abeliophyllum distichum Nakai flower extracts against oxidative DNA damage was evaluated by DNA cleavage assay using $\varphi \mathrm{X}-174$ RF I plasmid DNA and intracellular DNA migration assay. The plasmid DNA cleavage assay using $\varphi \mathrm{X}-174 \mathrm{RF}$ I plasmid DNA was used as an initial approach to determine whether aqueous fraction with the antioxidant activity may inhibit the oxidative DNA damage induced by hydroxyl radical or $\mathrm{Fe}^{2+}$ ion or not. The lower concentrations of EtOAC fraction did not show the inhibitory effect on DNA damage, however, higher concentrations such as 40 and $200 \mu \mathrm{g} / \mathrm{ml}$ revealed 62 and $84 \%$ of inhibitory effect, respectively (Fig. 4). The inhibitory effect on DNA damage of aqueous fraction was low as $17 \%$ at $200 \mu \mathrm{g} / \mathrm{ml}$.

Intracellular DNA migration assay is a sensitive biomarker of the DNA damage. The aqueous fraction from Abeliophyllum distichum Nakai inhibited DNA migration induced by hydroxyl

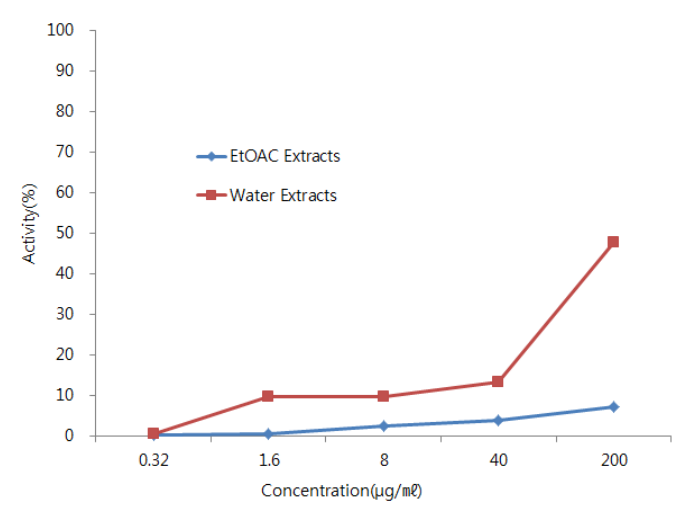

Fig. 3. $\mathrm{Fe}^{2+}$ Chelating activity of the flower extracts from Abeliophyllum distichum Nakai. The absorbance values were converted to chelating activity (\%) against extract concentration in $\mu \mathrm{g}$ extract per $\mathrm{ml}$ reaction volume. radical in a dose-dependent manner. The results indicated that no inhibitory effect was found in low concentrations of both aqueous and EtOAC fractions, whereas little effect was found at $200 \mu \mathrm{g} / \mathrm{ml}$ (Fig. 5).

\section{Cytotoxity}

We demonstrated the cytotoxity of Abeliophyllum distichum Nakai flower extracts with NIH3T3 cells by MTT assay (Fig. 6). Both extracts (EtOAC and Water extracts) showed no cytotoxity even if the same concentration with the above antioxidant experiments.

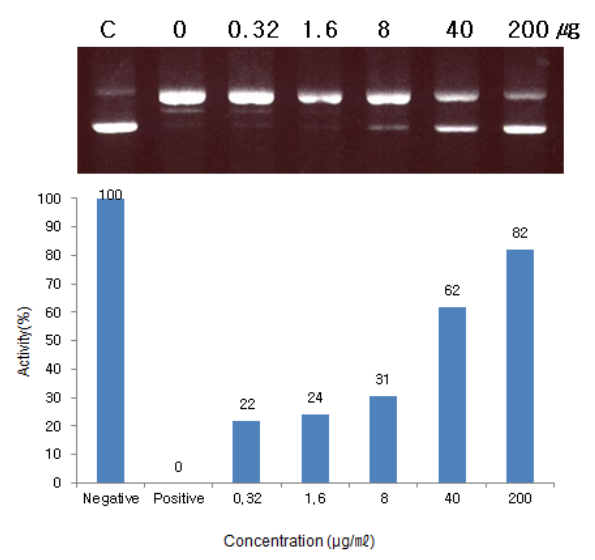

(A)

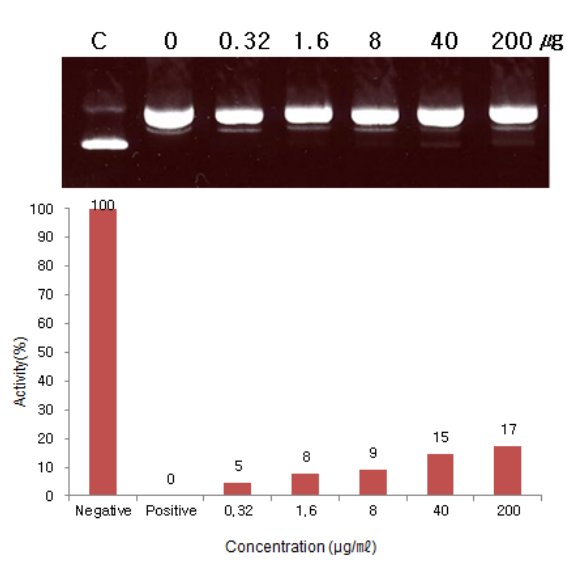

(B)

Fig. 4. Protective effect of flower extracts from Abeliophyllum distichum Nakai against DNA cleavage induced by hydroxyl radical. (A) EtOAC extract, (B) Hot water extract. Hydroxyl radical was generated from fenton reaction between $\mathrm{H}_{2} \mathrm{O}_{2}$ and $\mathrm{FeSO}_{4} . \mathrm{Fe}^{2+}$ ion generated from $\mathrm{FeCl}_{2}$. The plot means \% inhibition of flower extract against DNA cleavage induced by hydroxyl radical. 


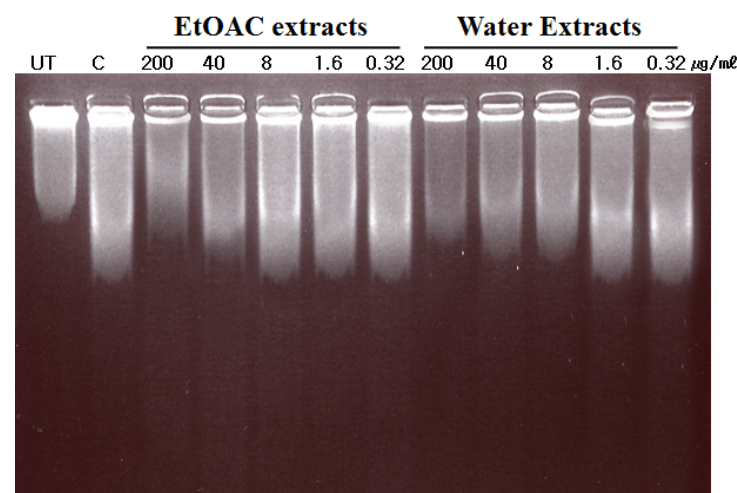

Fig. 5. Protective effect of the flower extracts from Abeliophyllum distichum Nakai against oxidative DNA damage by intracellular DNA migration assay. (UT) : Untreated control, (C) : Control. Numbers correspond to various concentrations of extracts.

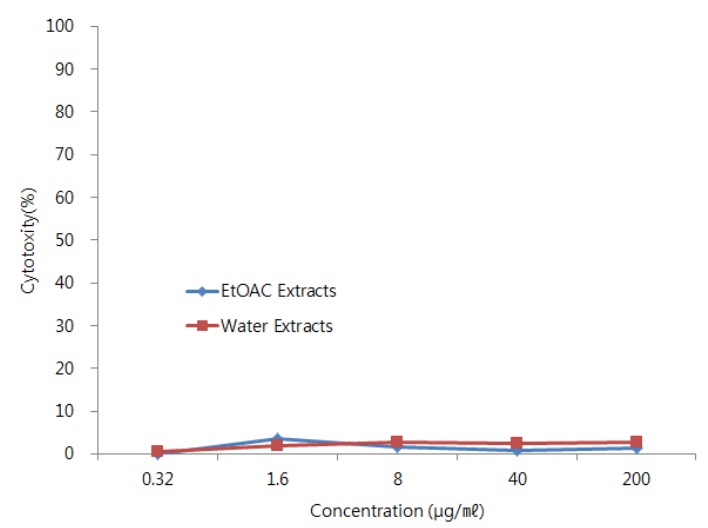

Fig. 6. Cytotoxity of the flower extracts from Abeliophyllum distichum Nakai by MTT assay with NIH 3T3 cells. NIH 3T3 cells were treated with various concentrations $(0.32,1.6,100,8$, $40,200 \mu \mathrm{g} / \mathrm{ml}$ ) of extracts for $24 \mathrm{hr}$. Cell viability was measured by MTS assay as described in materials and methods.

\section{GC/MS analysis}

The major 10 compounds were identified and listed by GC/MS (Fig. 7). Those were polyphenolic compounds such as coumaran, bensenacetic acid and vanllic acid, which may be related with antioxidant activities of Abeliophyllum distichum Nakai flower extracts.

\section{Discussion}

Recent studies have been focused on finding on neutral antioxidants from various kinds of medicinal plants and their extracts. Synthetic antioxidants are widely used to inhibit lipid

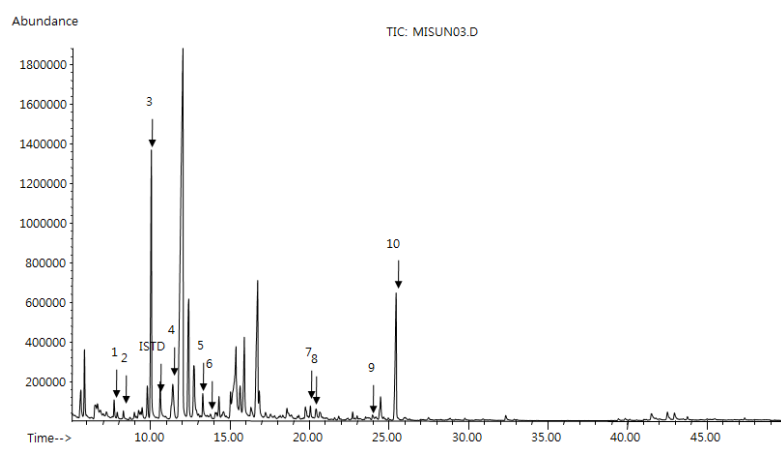

\begin{tabular}{ccc}
\hline \hline Peak No. & Compounds & $\begin{array}{c}\text { Peak area } \\
\text { / ISTD peak area }\end{array}$ \\
\hline 1 & Coumaran & 0.55 \\
2 & Benzeneacetic acid & 0.37 \\
3 & 8-Hydroxylinalool & 6.10 \\
4 & 4-hydroxy-Benzeneethanol & 2.13 \\
5 & 2-methoxy-benzoic acid & 0.34 \\
6 & Vanillic acid & 0.24 \\
7 & Phytol & 0.36 \\
8 & Pulegone & 0.32 \\
9 & Cinnamic acid & 0.15 \\
10 & 4-methoxy-Phenol acetate & 3.67 \\
\hline
\end{tabular}

Fig. 7. GC/MS chromatogram and main compounds of flower extracts from Abeliophyllum distichum Nakai. The compounds were identified with the aid of the Wiley275 mass spectral database (Hewlett-Packard).

peroxidation of oils, anti-aging process and prolong the shelf-life of food products, however, there is widespread agreement that some synthetic antioxidants such as butylhydroxyanisole and butylhydroxytoluene need to be replaced with natural antioxidants due to their potential health risks and toxidity (Li et al., 2008 and Safer and Al-Nughamish, 1999).

Abeliophyllum distichum Nakai is momotypic taxon of Oleaceae and endemic to Korea. This deciduous shrub is related to the forsythia, but differs in that it has white(rather than yellow) flowers that open in early spring before true forsythia. Now in Korea, the 5 natural habitats of Abeliophyllum distichum Nakai have been designated and protected as a natural monument. Consequently, the study of Abeliophyllum distichum Nakai has been emphasized on the botanical characterization and mass propagation.

Earlier study in our lab has been shown antioxidant activities and protective effect of Abeliophyllum distichum Nakai leaves and possibility of its application (Park, 2011). Therefore, the present study was designed to evaluate the inhibitory effect on 
oxidative DNA damage of extracts from Abeliophyllum distichum Nakai flower by analyzing its antioxidant activities and cytotoxity.

The role of an antioxidant is to remove free radicals. The mechanism for antioxidants to remove free radical involves donating hydrogen to a free radical and hence its reduction to an unreactive species through removing the odd electron feature which is responsible for radical reactivity. DPPH radical scavenging assay is based on these mechanism (Wang et al., 2008).

In non-cellular systems, EtOAC fractions showed the high scavenging activities in DPPH and hydroxyl radical as 93.41 and $98.43 \%$ at $200 \mu \mathrm{g} / \mathrm{ml}$, respectively. In aqueous fractions, 86.93 and $41.33 \%$ of scavenging activities were found in DPPH and hydroxyl radical assay in same concentration. In contrast, $\mathrm{Fe}^{2+}$ chelating ability was $7.38 \%$ and $47.68 \%$ in aqueous and EtOAC fractions at $200 \mu \mathrm{g} / \mathrm{ml}$, respectively. The scavenging activity of hydroxyl radicals by both aqueous and EtOAC fractions from Abeliophyllum distichum Nakai flower demonstrates its effectiveness against biologically generated radicals. Moreover, the chelation of $\mathrm{Fe}^{2+}$ ion also showed its effectiveness on radical production inhibition.

ROS have been associated with pathogenic processes including carcinogenesis through direct effects on DNA directly and by acting as a tumor promoter (Wiseman and Halliwell, 1996). Cellular systems generate a variety of ROS such as superoxide, hydrogen peroxide and hydroxyl radical. Hydroxyl radical is an extremely reactive species, reacting with virtually all known bio-molecules at diffusion-limited rates of reactions $\left(\sim 10^{7}-10^{10} \mathrm{M} / \mathrm{s}\right)$. Moreover, this radical has been shown to per-oxidize lipids, oxidize protein, and promote DNA strand scission (Grisham, 1992). This DNA damage by hydroxyl radical has been shown to play a key role in the carcinogenesis (Barreto et al., 2005).

The protection ability from DNA damage of extract fractions was found by $\varphi \mathrm{X}-174$ RF I plasmid DNA and intracellular DNA migration assay. The present results indicated that extracts from Abeliophyllum distichum Nakai flower inhibits oxidative damage.

Therefore, these results indicated that the extracts from Abeliophyllum distichum Nakai flower had high oxidative activities and protective effect on DNA damage and showed the possible use of Abeliophyllum distichum Nakai flower as a effective natural antioxidants.

\section{Acknowledgement}

This research was supported by Basic Science Research Program through the National Research Foundation of Korea (NRF) funded by the Ministry of Education, Science and Technology (2011-0025272).

\section{Literature Cited}

Ali, S., N. Kasoju, A. Luthra, A. Singh, H. Sharanabasava and A. Sahu. 2008. Indian medicinal herbs as sources of antioxidants. Food Res. Int. 41:1-15.

Ames, B.N. 1983. Dietary carcinogens and anticarcinogens: oxygen radicals and degenerative diseases. Science 221: 1256-1264.

Auudy, B., F. Ferreira, L. Blasina, F. Lafon, F. Arredondo and R. Dajas. 2003. Screening of antioxidant activity of three Indian medicinal plants, traditionally used for the management of neurodegenerative diseases. J. Ethnopharmacol. 84:131-138.

Barreto, R., S. Kawakita, J. Tsuchiya, E. Minelli, K. Pavasuthipasit, A. Helmy and F. Marotta. 2005. Metal-induced oxidative damage in cultured hepatocytes and hepatic lysosomal fraction: beneficial effect of a curcumin/absinthium compound. Chinese J. Digest. Dis. 6:31-36.

Cerutti, P.A. 1994. Oxy-radicals and cancer. Lancet 344(8926): 862-863.

Cho, E.S., K.W. Lee and H.J. Lee. 2008. Cocoa procyanidins protect PC12 cells from hydrogen-peroxide-induced apoptosis by inhibiting activation of $\mathrm{p} 38 \mathrm{MAPK}$ and JNK. Mutat. Res. 640:123-130.

Choudhary, R.K and P.L. Swarnkar. 2011. Antioxidant activity of phenolic and flavonoid compounds in some medicinal plants of India. Nat. Prod. Res. 25:1101-1109.

Grisham, M.B. 1992. Reactive oxygen metabolism. In Grisham M.B. (ed.), Reactive Metabolites of Oxygen and Nitrogen in Biology and Medicine, RG Landers Company, Austin, TX. p. 39.

Jung, Y. and Y. Surh. 2001. Oxidative DNA damage and cytotoxicity unduced by copper-stimulated redox cycling of salsolinol, a neurotoxic tetrahydroisoquinoline alkaloid. Free 
Radic. Biol. Med. 44:1407-1417.

Kirmizibekmez, H., C. Bassarello, S. Piacente, E. Celep, I. Atay and G. Mercanoğlu. 2009. Phenolic compounds from Hypericum calycinum and their antioxidant activity. Nat. Prod. Commun. 4:531-534.

Koleckar V., K. Kubikova, Z. Rehakova, K. Kuca, D. Jun and L. Jahoda. 2008. Condensed and hydrolysable tannins as antioxidants influencing the health. Mini Rev. Med. Chem. 8:436-47.

Li, H.B., C.C. Wong, K.W. Cheng and F. Chen. 2008. Antioxidant properties in vitro and total phenolic contents in methanol extracts from medicinal plants. Food Sci. Technol.-LEB 41:385-390.

Park, J.H. 2011. Antioxidant activities and inhibitory effect on oxidative DNA damage of extracts from Abeliophylli distichi Folium. Kor. J. Herbiology 26(4):95-99 (in Korean).

Rosenkranz, A.R., S. Schmaldienst, K.M. Stuhlmeier, W. Chen, W. Knapp and G.A. Zlabinger. 1992. Microplate assay for the detection of oxidative products using 2',7'-dichlorofluo- rescin-diacetate. J. Immunol. Methods 156:39-45.

Safer, A.M. and A.J. Al-Nughamish. 1999. Hepatotoxicity induced by the anti-oxidant food additive butylated hydroxytoluene $(\mathrm{BTH})$ in rats: an electron microscopical study. Histol. Histopathol. 14:391-406.

Smirnoff, N. and Q.J. Cumbes. 1989. Hydroxyl radical scavenging activity of compatible solutes. Phytochemistry 28:10571060.

Stadtman, E.R. 1992. Protein oxidation and aging. Science 257: 1220-1224.

Sun, Y. 1990. Free radicals, antioxidant enzymes and carcinogenesis. Free Radical Bio. Med. 8:583-599.

Wiseman, H. and B. Halliwell. 1996. Damage to DNA by reactive oxygen and nitrogen species: role of inflammatory disease and progression to cancer. Biochem. J. 313:17-29.

Wang, H., X.D. Gao, G.C. Zhou, L. Cai and W.B. YaO, 2008. In vitro and in vivo antioxidant activity of aqueous extract from Choerospondias axillaris fruit. Food Chem. 106:888895.

(Received 10 June 2013 ; Revised 22 June 2013 ; Accepted 28 June 2013) 